\title{
THE DESIGN OF NYLON FIBER/IPHENOLIC BALLISTIC COMPOSITES BY THE IMPLEMENTATION OF THE FULL FACTORIAL EXPERIMENTAL DESIGN
}

Dimko Dimeski*, Vineta Srebrenkoska

Faculty of Technology, University “Goce Delčev“, Štip, Republic of Macedonia

In the present work, the attempt was made to assess the applicability of the full factorial experimental design in predicting the ballistic strength of nylon fiber/ phenolic composite laminates when subjected to a perpendicular impact by a solid projectile. In the study we used a number of ballistic composites $(20 \mathrm{~cm}$ x $20 \mathrm{~cm}$ ) with different areal weight (thickness) and fiber/resin ratio. The composites were made with an open mold high pressure, high-temperature compression of prepreg layers made of plain woven ballistic nylon fabric and polyvinyl butyral modified phenolic resin of the resole type.

The preparation of the composite experimental samples was conducted in accordance with the $2^{2}$ full factorial experimental design. The areal weight of the composites was taken to be the first factor and the second was the fiber/resin ratio. The first factor low and high levels were set at $2 \mathrm{~kg} / \mathrm{m}^{2}$ and $9 \mathrm{~kg} / \mathrm{m}^{2}$, respectively, and for the second factor - at $80 / 20$ and 50/50, respectively. To approximate the response i.e. the ballistic strength of the composites within the study domain $(2-9) \mathrm{kg} / \mathrm{m}^{2} \times(80 / 20-50 / 50)$ fiber/resin ratio, the first-order linear model with the interaction was used. The influence of each individual factor to the response function was established, as well as the influence of the interaction of the two factors. We found out that the estimated first-degree regression equation with the interaction gave a very good approximation of the experimental results of the ballistic strength of composites within the study domain.
(ORIGINAL SCIENTIFIC PAPER) UDC 677.4:678.6

Key words: nylon fibers, ballistic composites, factorial design, regression equation

\section{Introduction}

A composite material is a special combination of two or more components that are dissimilar in form and properties. In composites the maximal use of each component favorable properties is made, resulting in a superior material. There are many forms of polymeric composites but, regardless of the type, they are all formed by a resin matrix of low modulus material and reinforcing fibers with the and stiffness properties that range from the factor of ten to the factor of thousand times higher than those of the matrix [1-3]. The reinforcing fibers in the composite material are responsible for carrying the vast majority of any loading applied, whereas the matrix simply binds the reinforcing fibers together and distributes the loading evenly throughout the fibers. The resin matrix also has several more minor roles, such as protecting the fibers from environmental influences and carrying a very small proportion of the applied load [4, 5].

Fiber/resin composites are mainly used as structural materials. Because of their very high strength-to-weight ratio these materials have substituted many traditional materials in applications where the strength and weight are of crucial importance, especially in military and aerospace industries.
Laminated textile composite armor packages made of high-strength ballistic fabrics are widely used as armor panels in the body armor to stop bullets of short-barrel small arms and fragments of artillery ammunition and mines.

Textile composites suit this role well because of their superior stiffness and strength-to-weight properties over many other classes of materials. The utilization of textile composites provides mass efficiency with enhanced survivability, movability and transportability of people and devices.

The impact damage mechanism of composite materials can be categorized as either being a low velocity impact or a high velocity impact, which essentially pertains to the kinetic energy state of the impacting projectile. However, regardless of the categorization, the impact damage as a whole is defined as the application of a high strain rate on the material [6]. The low velocity impact damage can be defined as an event that applies a quasi static load to the material, which is an event that has the duration sufficiently long enough for the entire composite structure to respond to the impact. However, a high velocity impact can be defined as an event where

\footnotetext{
*Author address: Dimko Dimeski, Univerzitet “Goce Delčev”, Tehnološko-tehnički fakultet,

Miro Baraga bb, Probištip, Republika Makedonija

E-mail: dimko.dimeski@ugd.edu.mk

The manucsript received: January, 15, 2014.

Paper accepted: March, 14, 2014.
} 
the composite structure does not have time to respond to the impact loading, which is usually characterized by the stress wave propagation through the material with the majority of damages being inflicted in a localized area.

The energy-absorption characteristics of a laminate subjected to the ballistic impact depend on constituent material properties (fiber and resin), laminate and projectile parameters and impact conditions $[6,7]$. The influence of some of these parameters on the perforation of laminate plates has been studied. One of the main parameters affecting perforation i.e. ballistic strength is laminate thickness. An alternative and related parameter is the areal weight of the laminate; the other main parameter is fiber/resin ratio into the composites which greatly affects overall mechanical properties of the laminate including the impact resistance.

One of the first recorded examples of the use of the soft fibrous armor was by the medieval Japanese who used the armor manufactured of silk [8]. The next generation of ballistic vests was introduced by the US military during the World War II. The "flak jacket," constructed of ballistic nylon provided the protection primarily from munitions fragments. Later, during the Korean War, the nylon fiber was used in a hard armor, namely, nylon/phenolic laminate was used in US Army M1 helmet [9].

Ballistic composites are traditionally developed by using the legacy knowledge, and their development relies extensively on the use of fabricate-and-test approach. Since this approach is not only economically unattractive, but is often associated with significantly longer lead times, it has gradually become complemented by the appropriate cost- and time-efficient Computer Aided Engineering (CAE) analyses [10]. Based on the empirical knowledge, in this study we tried to find a mathematical correlation between two main factors affecting the ballistic strength of nylon/phenolic composites - the areal weight and the fiber/resin ratio of the composites.

\section{Experimental procedure}

The thermosetting phenolic resin with the dry content of $76 \%$ and gel time at $150{ }^{\circ} \mathrm{C}$ of $120 \mathrm{~s}$ was used as a matrix. The resin was modified with polyvinyl butyral with the dry content $>98 \%$, supplied by Plasta Erkner, Germany. The purpose of the modification was to make the intrinsically brittle phenolic resin more flexible. It is a well-known fact that the flexibility of the matrix system better contributes to the kinetic energy absorption of high- and low-velocity impact and its dissipation in the adjacent layers [11]. As reinforcement, a plain woven glass fiber fabric was used finished with phenolic resin compatible silane finish. The main features of the fabric are given in Table 1. The impregnation of the fabric was carried out on a semi-industrial vertical impregnating machine. Nylon/phenolic composites were taken in this study because of the cost favorability compared to highperformance fiber composites.
Table 1. Main properties of the nylon fabric

\begin{tabular}{lcc}
\hline \multicolumn{1}{c}{ Property } & Unit & Value \\
\hline Type of nylon & $/$ & 6.6 \\
Weave & $/$ & plain $(1 \times 1)$ \\
Thread count (warp x weft) & $/$ & $15 \times 15$ \\
Areal density & $\mathrm{g} / \mathrm{m}^{2}$ & $265 \pm 8$ \\
Yarn linear density & $\mathrm{tex}$ & 120 \\
Thickness & $\mathrm{mm}$ & 0.40 \\
Fabric tensile strength (warp x weft) & $\mathrm{N} / 5 \mathrm{~cm}$ & $4200 \times 4200$ \\
\hline
\end{tabular}

The laminated composites were produced by an open-mold compression at high pressure and the temperature of $155^{\circ} \mathrm{C}$ within 150 minutes for fully curing i.e. cross-linking of the resin. No post-curing treatment was conducted. During the impregnation, several factors were observed (resin viscosity, metering rolls gap on the impregnating machine, speed of impregnation $6 \mathrm{~m} / \mathrm{min}$, temperature $150{ }^{\circ} \mathrm{C}$ ) so that the required resin pick-up and its content in the prepreg was attained. The areal weight of the composites was adjusted simply by adding more prepreg layers in the press pack from the lowest to the highest area weight in accordance with the experimental design.

In the $2^{2}$ full factorial experimental design (FFED) we used in this study, the areal weight of the composite is taken to be the first factor, and the second factor is - fib$\mathrm{er} / \mathrm{resin}$ ratio. For the first factor the low and high levels are set at $2 \mathrm{~kg} / \mathrm{m}^{2}$ and $9 \mathrm{~kg} / \mathrm{m}^{2}$, respectively, and for the second factor - at $80 / 20$ and $50 / 50$, respectively. Within this relatively narrow areal weight region, the linear dependence of the ballistic strength vs. areal weight was assumed. With that assumption, we took the first-order linear model with interactions to predict the response function i.e. the ballistic strength of the composites within the stated study domain $(2-9) \mathrm{kg} / \mathrm{m}^{2} \times(80 / 20-50 / 50)$ fiber/resin ratio.

The full factorial experimental design allows making mathematical modeling of the investigated process in the vicinity of a chosen experimental point within the study domain $[12,13]$. To include the whole study domain we chose the central points of both ranges to be the experimental points. For the areal weight of the composites, we chose the experimental point to be $5,5 \mathrm{~kg} / \mathrm{m}^{2}$, and for the resin content , the experimental point - $35 \%$ (which corresponds to previously defined levels for fiber/ resin ratios).

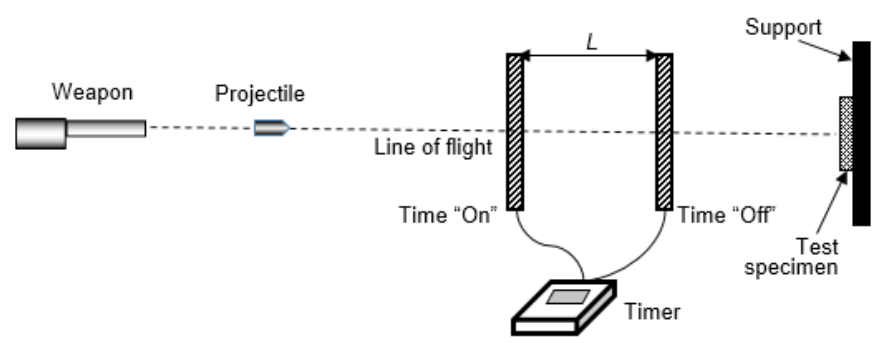

Figure 1. Ballistic test setup 
All tests were conducted with a standard $1.1 \mathrm{~g}$ chiselnosed, a fragment simulating projectile which is non-deformable, made of quenched and tempered steel with a flat rectangular tip. Figure 1 shows the ballistic test setup. V50 measurement is based on measuring the time for which the projectile passes through two photo-sensitive frames which are positioned at a fixed distance, L. The balli-stic limit velocities, V50, are calculated in accordance with the NATO standard STANAG 2920 calculation method [14]. V50 property presents $50 \%$ probability of the penetration i.e. non-penetration of the projectile into the test specimen (composite plate) and is a statistical measure developed by the US military.

In accordance with the FFED procedure, $4\left(2^{2}\right)$ trails are needed i.e. all possible combinations of the variables are tested.

The coding of the variables is conducted in accordance with Table 2.

Table 2. Coding convention of variables

\begin{tabular}{|c|c|c|c|}
\hline & $\begin{array}{l}\text { Areal } \\
\mathrm{kg} / \mathrm{m}^{2}\end{array}$ & weight, & Resin content, $\%$ \\
\hline Zero level, $x_{i}=0$ & & 5.5 & 35 \\
\hline Interval of variation & & 3.5 & 15 \\
\hline High level, $x_{i}=+1$ & & 9 & 50 \\
\hline Low level, $x_{i}=-1$ & & 2 & 20 \\
\hline Code & & $x_{1}$ & $x_{2}$ \\
\hline
\end{tabular}

\section{Results and discussion}

The test results are presented in Table 3 together with the experimental matrix.

Table 3. Experimental matrix with results

\begin{tabular}{ccccc}
\hline Trials & & & \multicolumn{2}{r}{$\begin{array}{c}\text { Nylon composite } \\
\text { V50, (m/s) }\end{array}$} \\
\hline 1 & -1 & -1 & +1 & 218.4 \\
2 & 1 & -1 & -1 & 441.9 \\
3 & -1 & 1 & -1 & 199.1 \\
4 & 1 & 1 & +1 & 405.0 \\
-1 Level & $2 \mathrm{~kg} /$ & $20 \%$ & - & - \\
+1 Level & $9 \mathrm{~kg} / \mathrm{m}^{2}$ & $50 \%$ & - & - \\
\hline
\end{tabular}

By implementing the $2^{2}$ full factorial experimental design we found out that the response function in coded variables, $y_{\mathrm{k}}$, is:

$$
y_{k}=316,10+107,35 x_{1}-14,05 x_{2}-4,40 x_{1} x_{2} \text {. }
$$

and in engineering or natural variables, $y_{n}$ :

$$
y_{n}=164,0571+33,6048 x_{1}-0,4757 x_{2}-0.0838 x_{1} x_{2} \ldots
$$

In the FFED the term $x_{1} x_{2}$ is the interaction between the factors which might also have the influence on the response, in our case V50 value.

By analyzing the regression equation it should be noted that the main positive contribution to the V50 is given by the areal weight of the composites i.e. V50 is directly proportional to the areal weight of the composites. On the other hand, the resin content of the composite has the inversely proportional effect on the ballistic strength which means, the higher the resin content, the lower the ballistic strength. The influence of the areal weight is two orders of magnitude greater than the influence of the resin content. The interaction of the two factors, with the coefficient of -0.0838 has a negligible negative effect on the ballistic strength which is of one order of magnitude smaller than the influence of the resin content.

To validate the implementation of the FFED in the study and the assumed model, theoretically calculated results (Eq. 2) were compared with the experimental values for the composites with the areal weight of 2, 3, 4, $5,6,7,8$ and $9 \mathrm{~kg} / \mathrm{m}^{2}$ and the fixed resin content of 35 vol. \%. This comparison can be conducted with any other value for the resin content as long as it is within the study domain. The results are presented in Figure 2.

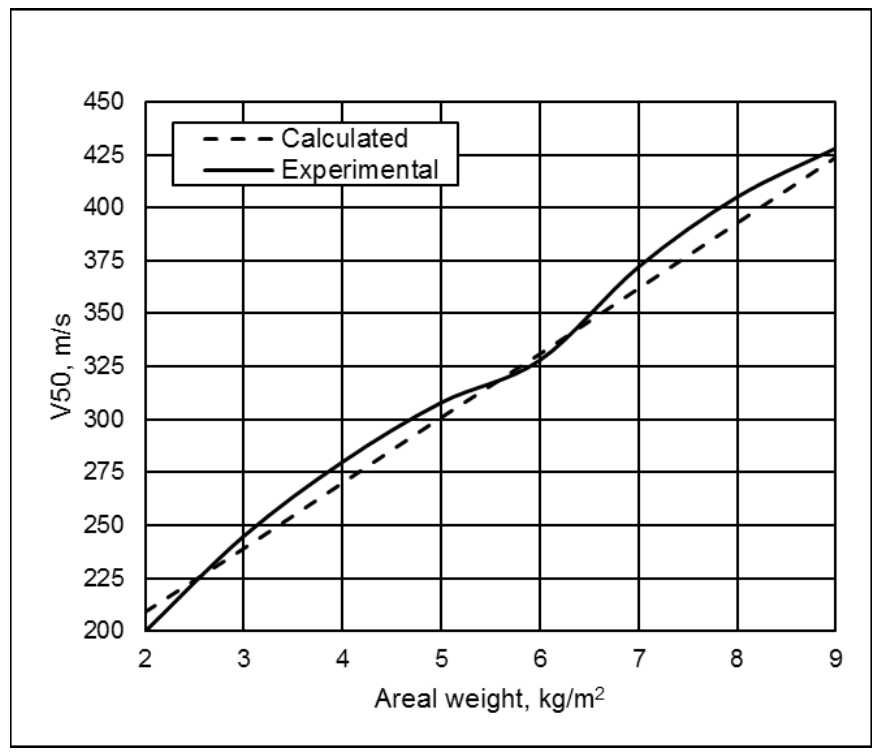

Figure 2. Theoretical vs. experimental values of V50

As it can be seen in Fig. 2, there is a good agreement between calculated and experimental values of V50. All calculated values are placed in a straight line which is in accordance with the assumed model of the experiment and are in close proximity of the experimental data.

How do we design composites using the regression equation?

- For a given request for the ballistic strength $\mathrm{V} 50$, by the substitution of $y_{n}$, in the equation (2), the areal weight of the composites can be calculated and then the appropriate number of prepreg sheets used in fabrication 
of the composites

- For a given weight limit ( $x_{1}$ factor) by the su-bstitution of $x_{1}$ in Eq. 2, $y_{n}$ i.e. the value of V50 can be calculated.

In both above cases the resin content ( $x_{2}$ factor) has to be fixed at $20 \%$ for the most favorable outcome.

\section{Conclusion}

- For the range of the areal weight and for the range of the resin content the experimental measurements of the ballistic strength of composite laminates were carried out by implementing the $2^{2}$ full factorial experimental design. A correlation equation was established for V50 as a function of the areal weight and the resin content of the composites. A very good agreement was found between experimental and calculated values. It was observed that if the study domain is precisely established (narrow enough), the full factorial experimental design can be employed in order to give good approximation of the response i.e. V50 value.

- V50 is directly proportional to the areal weight of the composites and inversely proportional to the resin content. The areal weight is a more dominant factor than the resin content.

\section{References}

[1] G.Zagianov, G. Lozinsky, Composite Materials in Aerospace Design, Chapman \& Hall, 1996 p.1-3.

[2] L.C. Lin, A. Bhatnagar, and H.W. Chang, Ballistic Energy Absorption of Composites, Proceedings of the 22nd SAMPE International Technical Conference, (1990) 1-13.

[3] J.G. Donovan, B. Kirkwood, and F. Figucia, Development of Lower Cost Ballistic Protection, Technical Report Natick/TR-85/019L, U.S. Army Natick RD\&E Center, (2008) $23-28$.

[4] J.W. Song and G.T. Egglestone, Investigation of the PVB/ PF Ratios on the Crosslinking and Ballistic Properties in Glass and Aramid Fiber Laminate Systems, Proceedings of the 19th SAMPE International Technical Conference, (1987) 108-119

[5] H. van der Werff, U. Heisserer and S. L. Phoenix, Modelling of Ballistic Impact on Fiber Composites, Personal Armour Systems Symposium, Quebec City (2010) 87 - 95.

[6] M. J. N. Jacobs and J. L. J. van Dingenen, Ballistic Protection Mechanisms in Personal Armour, Journal of Materials Science, 36(13) ( 2001) 3137-3142.

[7] H.Zeer., C. Hsieh, Energy absorption processes in fibrous composites, Materials Science \& Engineering A-Structural Materials Properties Microstructure \& Processing. 246(12) (1998) 161-168.

[8] R.Laible, E.Barron, in Ballistic Materials and Penetration Mechanics, R.Laible, Ed., Elsevier Publishing Co, New York, 1980, 124136.

[9] https://www.ncjrs.gov/pdffiles1/nij/189633.pdf, accessed 29/10/2013

[10] M.Gruicic,et al, A simple model for the prediction of the ballistic limit in thick-section composite laminate, IJERP, 2(2) (2013) 84 - 92

[11] W. Tayloret al, Modeling ballistic impact into flexible materials, AIAA Journal, 2(12) (1990) 32 - 46
[12] W.Hunter, S.Hunter, Statistics for Experimenters:Design innovation and discovery, John Wiley and Sons, New York, 2005, p. 148

[13] G.Box, D.Behnken, Some new two level designs for the study of quantitative variables, Technometrics 2(4) (2006) $455-475$

[14] NATO Standardization Agency, STANAG 2920-Ballistic test method for personal armor materials and combat clothing, edition 31 July 2003 
Izvod

\section{DIZAJN BALISTIČKOG KOMPOZITA OD NAJLONSKIH VLAKNA / FENOLNIH SMOLA PRI- MENOM PUNOG FAKTORIJALNOG EKSPERIMENTALNOG DIZAJNA}

Dimko Dimeski, Vineta Srebrenkoska

Tehnološko-tehnički fakultet, Univerzitet “Goce Delčev”, Stip, Republika Makedonija

$U$ radu je napravljen pokušaj da se proceni primenljivost punog faktorljalnog dizajna eksperimenata u predvidjanju balističke čvrstoće najlonska vlakna/fenolna smola kompozitnih laminata kada su podvrgnuti normalnom balističkom udaru tvrdim projektilom. U istrživanju je korišćeno više balističkih kompozita $(20 \mathrm{~cm}$ x $20 \mathrm{~cm})$ sa različnom masom i različnim odnosom vlakna/smola. Kompoziti su izrađeni u otvorenom kalupu presovanjem slojeva preprega na visokoj temperaturi. Prepreg je na bazi najlonske (balističke) tkanine platnenog prepletaja i fenolne smole modifikovane polivinil butiralom.

Priprema uzoraka je bila u skladu $2^{2}$ punog faktorljalnog dizajna eksperimenata. Površinska masa kompozita je uzeta kao prvi faktor, a drugi - odnos vlakna/smola. Donji i gornji nivo prvog faktora su $2 \mathrm{~kg} / \mathrm{m}^{2}$ and $9 \mathrm{~kg} / \mathrm{m}^{2}$, a drugog - 80/20 i 50/50. Korišćen je linerni model prvog reda sa interakcijom da bi aproksimirao odziv t.j. balistička čvrstoća kompozita u istraživačkom domenu $(2-9) \mathrm{kg} / \mathrm{m}^{2} \times(80 / 20-50 / 50)$ odnos vlakna/smola. Određen je uticaj svakog pojedinačnog faktora na funkciju odziva kao i uticaj interakcije među faktorima. Utvrđeno je da proračunska regresiona jednačina prvog reda sa interakcijom daje veoma dobro predviđanje eksperimentalnih rezultata balističke čvrstoće kompozita u istraživačkom domenu.
(ORIGINALNI NAUČNI RAD)

UDK 677.4:678.6

Ključne reči: najlon vlakno, balistički kompoziti, faktorni plan, regresiona jednačina 